Ajibola, I.M., Saheed, D.O., \& Adedoyin, L. (2020). Impact of Microfinance Institutions on Financial Literacy in North Central Geo-Political Zone Nigeria. Copernican Journal of Finance \& Accounting, 9(4), 9-25. http://dx.doi.org/10.12775/CJFA.2020.019

\author{
Ibrahim Majeed Ajibola* \\ Kwara State University \\ Daud Omotosho Saheed ${ }^{* *}$ \\ Kwara State University \\ LUKMAN Adedoyin ${ }^{* * *}$ \\ Federal Polytechnic Offa
}

\title{
IMPACT OF MICROFINANCE INSTITUTIONS ON FINANCIAL LITERACY \\ IN NORTH CENTRAL GEO-POLITICAL ZONE NIGERIA
}

Keywords: financial literacy, saving mobilization, e-banking, financial decisions.

J E L Classification: G21, G28, D14, D19, C23.

Abstract: Inclusive financial literacy through Microfinance Institutions activities is becoming a policy issue in both developed and developing nations of the world as it has been perceived as a veritable tool for economic development. This work examines the

Date of submission: September 18, 2020; date of acceptance: January 3, 2021.

*Contact information: ajibolamagaji@gmail.com, Department of Accounting and Finance, Kwara State University, Malete, Nigeria, phone: +2347032873780; ORCID ID: https://orcid.org/0000-0003-2293-3453.

** Contact information: oshoprint@gmail.com, Department of Accounting and Finance, Kwara State University, Malete, Nigeria, phone: +2347036215657; ORCID ID: https://orcid.org/0000-0003-1365-2860.

*** Contact information: orimustrock@yahoo.com, Department of Accountancy, The Federal Polytechnic, Offa, Nigeria, phone: +2348032440434; ORCID ID: https://orcid. org/0000-0001-5459-3364. 
impact of Microfinance Institutions on financial Literacy in North Central Geo-Political Zone Nigeria. The specific objectives are to establish the relationship between saving mobilization as microfinance institutions operations and financial literacy, analyze the effect of microfinance institutions accessibility on E-banking platform usage and identify the effects of microfinance institutions activities on the financial decisions of the rural dwellers. Descriptive design method was adopted; 50 respondents was selected from each of the six Microfinance Institutions that was selected from each of the six states of the north central geo-political zone that serve as the fair representation of the population under study a total of 1800 questionnaires were administered out of which 1494 was returned. Data for the study were collected primarily through questionnaire from the 1494 respondents that serve as the fair representations for the population under study. The formulated hypotheses were tested with the aid of regression and correlation while preliminary test was done with the aid of Kolmogorov-Smirnov and Shapiro Wilk with a view to ascertain the normality of the data. Similarly, Reliability test was conducted with the aid of Cronbach's Alpha. The overall results of the regression analysis reveals that a positive relationship exist between MFIs activities and financial literacy given cognizance to the reported coefficients on the adopted variables. Therefore, it was recommended that Government should promote financial sector deepening by licensing more microfinance institutions, to promote accessibility to finance among its populous to improve the level of financial literacy in Nigeria. This will increase their ability to save and borrow thereby contribute positively to economic development.

\section{INTRODUCTION}

The current trend in economy world has not only made financial literacy an important knowledge which a sizeable portion of a state must acquire but rather becomes an imperative essential tool for survival in the face of the global pandemic which has voraciously induce all forms of economics activities adversely. The low level of financial literacy especially among the rural dwellers has no doubt resulted to some forms of poor financial investment and decision due to their inability to clearly identified and select an investment option that suit their risk preference this will no doubt have an impending effect on both individual finances and the entire financial system. Thus, the need to accelerate personal financial literacy and orientation should become policy issue in developed and developing countries. Low level of financial literacy in Africa is especially in Nigeria is becoming alarming among specific demographic groups, particularly those with low education background (Gine, 2013). The increasing incidence of poor financial investment in some Africa countries are in connection with the fact that an insignificant persons seek the help of financial advisors to make financial investment related decisions. However, low financial literacy among the rural dwellers usually affect their ability to save and to secure 
a comfortable investment plans considering the complexity of financial concepts (Lusardi, 2012).

Henri, Fred and Kemirembe (2015) maintain that financial literacy and orientation require the ability and capacity to do complex calculations with respect to financial investment plans and decisions. Lusardi (2008) opined that most of the empirical Studies carried out by the United States and other selected developing nations indicate that low level of education attainment is a major producing agent of financial illiteracy. Financial knowledge is the major ingredient for financial and investment decisions. Thus, financial literacy has become the lifetime skills that is require to succeed in today's complex economic environment in the face of the global pandemics (Kakande, 2013).

Most of the previous studies on the subject matter such as Masok (2011), Kakande (2013), Chibba (2009), Sanusi (2011), Abifarin and Bello (2018), Emeka and Udom (2019) and Adeola and Ikpesu (2019) among others that examined financial literacy related topics in Nigeria focused mainly on the role of financial institutions in promoting business enterprises and financial inclusion. This, to the best knowledge of the researchers, no study has been conducted with respect to how the operation of the microfinance institutions have promoted financial literacy among the people of North Central Geo-Political Zone in Nigeria given credence to the fact that the North Central Geo-Political Zone in Nigeria has the highest population of illiterates in Nigeria, particularly the rural dwellers considering the fact that microfinance institutions operate outside the formal sector. However, microfinance institutions constitute a potent development strategy tool that enables poor entrepreneurs to initiate their businesses as well as saving mobilizations which expand the circle of their economic activities. Therefore, the impact of microfinance institutions on financial literacy in Nigeria has not being fully researched on, it is imperative that the gap be filled by taking a look at how the microfinance institutions operations affect and promote financial literacy especially among the rural dwellers. To guide the thrust of this research work, the following hypotheses were tested:

H1: There is no significant relationship between saving mobilization of microfinance institutions operations and financial literacy.

H2: There is no significant effect of microfinance institutions accessibility on E-banking platform usage.

H3: There is no significant effect of microfinance institutions activities on the financial decisions of the rural dwellers. 


\section{LITERATURE REVIEW}

\section{Conceptual Review}

Financial literacy as a persons' minimal knowledge about financial terms such as money, inflation, interest rate, credit and others financial related concept (Greenspan, 2002). The ability, capacity, dexterity and skills of an individual to use all this information in making personal financial decisions. Socol (2014) opined that the concept of financial literacy restricted to knowledge and skill elements. More particularly, the concept of financial literacy now requires individual financial behavior, preference as well as self-discipline to ensure a better financial investment decision. Financial orientation and literacy is a broad concept that requires the translation of idea and knowledge for the purpose of wealth creation in terms of efficient saving and investment. Financial numeracy, literacy and orientation perhaps depend on the financial system and the framework in which individuals and communities operate.

Bayer and Douglas (2009) argue that low financial knowledge in this part of the world has promoted wrong financial plans and decisions which has induced the prosperity index in the nonproductive age of demography. The cardinal focus of financial numeracy and literacy is to give financial education and orientations to all and sundry specifically the rural dwellers in order to manage their finances diligently and intelligently, as a way of addressing information asymmetry associated with investment decisions in relation to investment products that offer high profits in the short term without considering the associated risks.

\section{THEORETICAL BACKGROUND}

\section{Learning Theory}

Learning theory was promulgated by Skinner (1953) who postulated that behaviour is associated with consequence based on the assumption that the behavior of an individual has direct link with their ability and capacity. Thus, the theory is mainly concern with the possibility of making certain decisions with respect to self-discipline and preference in connection with an impending consequence regarding how individual knowledge and exposure affect their de- 
cision making. Thus, it is important to note that financial literacy induce the skills and knowledge of individuals in making key financial and investment related decisions that affect their lives and considering the strategic role microfinance institutions play in relation to the financial literacy of low income earners and the rural dwellers that are mostly financially excluded.

\section{Empirical Review}

Mohamed and Mukhongo (2016) examine the effect of microfinance services on the financial performance of small and medium enterprises, in Mogadishu, Somalia. The data used for the study was collected through a structured questionnaire that was administered to the selected respondents that were purposively selected to serve as fair representation for the population under study. Regression model was adopted with the view to test for the significance of the study hypotheses. The results show that moderate positive relationship exists between financial sustainability, financial literacy, risk diversification and financial performance of microfinance institutions in Mogadishu, Somalia. In the light of the forgoing it was recommended that the microfinance institutions should expand their services to other parts of the country as a way of accelerating SMEs growth among the people of Mogadishu in Somalia.

Chibba (2009) empirically investigate the influence of financial literacy on financial decisions of micro finance institution clients in Embu County. Questionnaire was adopted as a tool for data collection. The collected date was analyzed using statistical package for social sciences (SPSS) computer program. Spearman's correlation was used to establish the nature of relationship that exist between the dependent variable and adopted proxies for the independent variables. The results show that financial illiteracy of certain portion of the demographic especially the rural dwellers about MFI operations had made some of them poorer because of wrong investment decisions. It was recommended that MFI should step up their training for their customers on financial literacy through a voucher scheme to enable the clients advance their financial management skills and dexterity.

Ajinaja and Odeyale (2018) examine Microfinance and the challenge of financial inclusion for SMEs development in Nigeria. The needed data was collected primarily through the use of questionnaire. The result of the finding reveal among many others that there is a negative significant relationship between loan to small enterprises and loan to rural areas in Nigeria in the period 
under study. It was therefore recommended that more micro finance institutions should operate at rural communities as a way of addressing the problem of financial exclusion the rural dwellers are confronted with.

Emeka and Udom (2019) investigate the impact of Microfinance in promoting financial inclusion in Nigeria from 1990 and 2014. A unit root test was conducted to establish the stationary of the adopted series to avoid spurious regression results. The findings indicate that all the explanatory variables were jointly significant in explaining the dependent variable. It was recommended that microfinance banks should operate majorly in local communities as a way of promoting financial inclusion among the rural dwellers.

From the literature review surveyed, it was found that the researchers who studied financial literacy were conducted outside the shore of Nigeria hence, leaving a geographical gap, even considering the fact that most of the active players in the informal sectors were said to be rural dwellers who knew little or nothing about financial decision. This study therefore presents an empirical analysis of how the activities of microfinance banks influence financial literacy in North Central Geo-Political Zone in Nigeria.

\section{The Research Methodology and the Course of the Research Process}

\section{Methodology}

This research makes use of survey research because a population with large number was brought under investigation. The population for this study comprises of all the microfinance institutions in North Central Geo-Political Zone in Nigeria. It is important to know that there are different types of microfinance institutions performing designated functions; however, this study purposely focus on the microfinance banks in North Central Geo-Political Zone in Nigeria. Due largely to the proximity of the North Central Geo-political Zone to the researchers which enable the researchers to easily obtain all the needed data for the purpose of this study from each of the topmost six microfinance banks that were purposively selected from each of the six states of North Central GeoPolitical Zone in Nigeria. It is important to know that each of the six selected states in North Central Geo-Political Zone in Nigeria has three senatorial districts just like every other state in Nigeria. A total of thirty-six microfinance institutions operators were purposively selected to serve as the fair representa- 
tion of the whole microfinance institutions in North Central Geo-Political Zone in Nigeria. Hence, the researcher selects a predetermined number of fifty (50) customers per MFI, the topmost two microfinance institutions were selected from each of the three senatorial districts of the six North Central Geo-Political Zone States in Nigeria to make a total of three hundred (300) customers per each of the six states of North Central Geo-Political Zone in Nigeria which include; Benue, Kogi, Kwara, Niger, Nasarawa and Plateau. Hence, a total of one thousand and eight hundred (1800) respondents were targeted to serves as fair representation of the population under study.

\section{Model Specification}

This model was adapted from the study of Emeka and Udom (2019). The study used, saving mobilization (SM), E-banking product (EBP) and financial decision (FD) as a proxy for the independent variable

$$
\mathrm{FIL}=f(\mathrm{MFIO})
$$

Where:

FIL = Financial literacy

MFIO = Microfinance institution operations

Where: FIL = SM, EBP and FD:

It then follows that

$$
\mathrm{FIL}=f(\mathrm{SM} ; \mathrm{EBP} ; \mathrm{FD})
$$

Substituting equation (2) into (1), a multivariate relationship is arrived at as follows;

$$
\mathrm{MFI}=\beta_{0}+\beta_{1} \mathrm{SM}+\beta_{2} \mathrm{EBP}+\beta_{3} \mathrm{FD}+\varepsilon_{\mathrm{i}}
$$

Where:

$\beta_{0}=$ Intercept of the model.

$\beta_{1}=$ Coefficient of each independent variable in the model.

$\varepsilon_{\mathrm{i}}=$ Error term 
The a-priori expectation of the above model posits a positive relationship between FIL proxy and the adopted surrogates for MFIO.

\section{ESTIMATION AND ANALYSES}

\section{Validity and Reliability Test for the Research Instrument}

The Content validity of this work was done through expert opinion for determining the appropriateness of the research instrument. In other to ensure the reliability of this work research instrument Cronbach's Alpha technique was adopted.

\section{Data Presentation, Analysis and Interpretation}

\section{Response Rate}

Table 1. Analysis of Response Rate

\begin{tabular}{|l|c|c|c|c|}
\hline \hline \multicolumn{1}{|c|}{ Respondents } & Total Distributed & Total Returned & $\begin{array}{c}\text { Unreturned } \\
\text { Questionnaire }\end{array}$ & Correctly filled \\
\hline \hline Selected MFIs Customers & 1800 & 1594 & 100 & 1494 \\
\hline TOTAL & 1800 & 1594 & 100 & 1494 \\
\hline \hline
\end{tabular}

S o u r c e : field survey.

A total of one thousand and eight hundred (1800) questionnaires were administered to the selected respondents which are drawn from the 36 microfinance institutions across the three senatorial district of North Central Geo-political zone in Nigeria. Only one thousand, four hundred and ninety four (1494) representing $83 \%$ of the administered questionnaires were returned and completed appropriately, two hundred and six (206) questionnaires, representing $11.4 \%$ of the questionnaires administered were returned but not duly completed, hence, invalid, while one hundred (100) questionnaires, representing 5.5\% of the total questionnaires administered were not returned. These analyses were based on the responses from the returned questionnaires administered to the purposively selected respondents that serve as fair representation of the population under study. 


\section{PreliminaRY ANALYSIS}

\section{Test of Normality}

Table 2. Tests of Normality

\begin{tabular}{|l|c|c|c|c|c|c|}
\hline \hline & \multicolumn{3}{|c|}{ Kolmogorov-Smirnov } & \multicolumn{3}{c|}{ Shapiro-Wilk } \\
\hline \hline & Statistic & Df & Sig. & Statistic & df & Sig. \\
\hline Saving mobilization & .368 & 1494 & .214 & .613 & 1494 & .325 \\
\hline $\begin{array}{l}\text { E-banking platform usage by the } \\
\text { rural dwellers }\end{array}$ & .165 & 1494 & .147 & .721 & 1494 & .261 \\
\hline $\begin{array}{l}\text { Financial decisions of the rural } \\
\text { dwellers }\end{array}$ & .161 & 1494 & .107 & .790 & 1494 & .059 \\
\hline \hline
\end{tabular}

a. Lilliefors Significance Correction

S o u r c e : author's survey, 2020.

The table above indicated that the data relating to each of the research variables were normally distributed as Kolmogorov-Smirnov and Shapiro Wilk test were not significant at $0.05(\mathrm{p}=0.214,0.147,0.107$ and $0.325,0.261$ and 0.059 respectively). Base on this result parametric statistical analysis was considered appropriate for this study.

Table 3. Reliability Test Using Cronbach's Alpha

\begin{tabular}{|l|c|c|}
\hline \hline \multicolumn{1}{|c|}{ Variable } & Cronbach's Alpha & N \\
\hline \hline Saving mobilization & 0.78 & 4 \\
\hline E-banking platform usage by the rural dwellers & 0.76 & 4 \\
\hline Financial decisions of the rural dwellers & 0.74 & $\mathbf{1 2}$ \\
\hline Overall & $\mathbf{0 . 7 2}$ & 4 \\
\hline \hline
\end{tabular}

S o u r c e : author's survey, 2020.

The table above shows that Cronbach's Alpha coefficient for each of the above variables is relatively high at $0.78 \%, 0.76 \%$ and $0.74 \%$ regressors respectively. The overall Cronabch's Alpha coefficient is 0.72 . This value is above the stand- 
ard margin of 0.70 . Hence, the scale is considered reliable base on the above cronbach's Alpha result.

\section{Correlation Coefficient Matrix among Variables}

Table 4. Correlation Table

\begin{tabular}{|l|l|c|c|c|}
\hline \hline & & SM & EBP & FD \\
\hline \hline \multirow{5}{*}{ SM } & Pearson Correlation & 1 & $.556^{* *}$ & $.517^{* *}$ \\
\cline { 2 - 5 } & Sig. (2-tailed) & & .000 & .000 \\
\cline { 2 - 5 } & $\mathrm{N}$ & 1494 & 1494 & 1494 \\
\hline \multirow{3}{*}{ EBP } & Pearson Correlation & $.526^{* *}$ & 1 & $.600^{* *}$ \\
\cline { 2 - 5 } & Sig. (2-tailed) & .000 & 1494 & 1494 \\
\cline { 2 - 5 } & N & 1494 & .000 \\
\hline \multirow{3}{*}{ FD } & Pearson Correlation & $.503^{* *}$ & $.600^{* *}$ & 1 \\
\cline { 2 - 5 } & Sig. (2-tailed) & .000 & 1494 & 1494 \\
\cline { 2 - 5 } & N & 1494 & .000 & \multirow{2}{*}{1} \\
\hline \hline
\end{tabular}

**. Correlation is significant at the 0.01 level (2-tailed).

S o u r c e : author's survey, 2020.

The table above addressed the multi-collinearity problem among the explanatory variables. In the light of the above it was revealed that the independent variables were not significantly correlated with each other given considering their individual coefficients which was below $0.70 \%$ significance margin level. Hence, the result suggests that there is no multi-collinearity problem among the variables. 


\section{EMPIRICAL ANALYSIS}

\section{Pearson Correlation}

Table 5. Correlations

\begin{tabular}{|l|l|c|c|}
\hline \hline \multirow{3}{*}{ SM } & \multicolumn{1}{|c|}{ SM } & FL \\
\hline \hline & Pearson Correlation & 1 & $.804^{* *}$ \\
\cline { 2 - 4 } & Sig. (2-tailed) & & .000 \\
\cline { 2 - 4 } & $\mathrm{N}$ & 1494 & 1494 \\
\hline \multirow{2}{*}{ FL } & Pearson Correlation & $.804^{* *}$ & 1 \\
\cline { 2 - 4 } & Sig. (2-tailed) & .000 & 1494 \\
\cline { 2 - 4 } & $\mathrm{N}$ & 1494 & \multicolumn{2}{|c|}{1400} \\
\hline \hline
\end{tabular}

**. Correlation is significant at the 0.01 level (2-tailed).

S o u r c e : author's computation, 2020.

The table above addressed the relationship between (FL) and (SM). Pearson correlation was used because of parametric nature the data which was detailed in the normality test that previous conducted. The correlation coefficient of the result is above 0.70 i.e Financial Literacy having correlation coefficient of 0.804 which implies a positive strong relationship between Financial Literacy and saving mobilization. 


\section{Regression coefficient}

Table 6. Coefficients ${ }^{\mathrm{a}}$

\begin{tabular}{|c|c|c|c|c|c|c|}
\hline & \multirow{2}{*}{ Model } & \multicolumn{2}{|c|}{ Unstandardized Coefficients } & \multirow{2}{*}{$\begin{array}{c}\begin{array}{c}\text { Standardized } \\
\text { Coefficients }\end{array} \\
\text { Beta }\end{array}$} & \multirow[t]{2}{*}{$T$} & \multirow[t]{2}{*}{ Sig. } \\
\hline & & B & Std. Error & & & \\
\hline \multirow[t]{4}{*}{1} & (Constant) & .301 & .074 & & 4.304 & .044 \\
\hline & Saving mobilization & .175 & .051 & .185 & 2.420 & .000 \\
\hline & $\begin{array}{l}\text { E-banking platform } \\
\text { usage by the rural } \\
\text { dwellers }\end{array}$ & .421 & .064 & .752 & 6.164 & .000 \\
\hline & $\begin{array}{l}\text { Financial decision } \\
\text { of the rural dwellers }\end{array}$ & .051 & .075 & .080 & .760 & .000 \\
\hline
\end{tabular}

a. Dependent Variable: Financial Literacy

S o u r c e : author's computation, 2020.

The above table detailed the regression result of the model. According the table 0.301 was reported for constant which implies that irrespective of other independent variables, financial literacy is constantly affected by 0.301 . Saving mobilization of the selected Micro finance institutions has a standardised coefficient of 0.185 . This means that for every $1 \%$ increase in saving mobilization of micro finance institutions operations, financial literacy increase by 0.185 . Furthermore, E-banking platform usage by the rural dwellers has a standardised coefficient of 0.752 which implies that for every $1 \%$ increase in E-banking platform usage by the rural dwellers, financial literacy increase by 0.752 . Finally, financial decision of the rural dwellers has a standardized coefficient of 0.80 . By implication, for every $1 \%$ increase in financial decision of the rural dwellers, will lead to financial literacy increase by 0.80 . However, the standard error of all the variables are very low given cognizance to their reported coefficient. By implication the lower the standard error, the more precise the estimates. In view of this one can draw a conclusion that all the adopted proxies for the independent variables were precise in estimating the parameters. 


\section{Model Summary}

Table 7. Model Summary

\begin{tabular}{|c|c|c|c|c|}
\hline \hline Model & $\mathbf{R}$ & R Square & Adjusted R Square & Std. Error of the Estimate \\
\hline \hline 1 & $.652^{\mathrm{a}}$ & .665 & .698 & .248 \\
\hline \hline
\end{tabular}

a. Predictors: (Constant), MFIO

S o u r c e : author's computation, 2020.

The table detailed the model summary describing it goodness of fit. Multiple correlation coefficients (R) of 0.652 posits a strong relationship between the financial literacy and the set of predictors as a whole. The coefficient of $\left(\mathrm{R}^{2}\right)$ stood @ 0.665 which implies that $66.5 \%$ of variation in the financial literacy being the dependent variable can be explained by the adopted surrogate for the independent variables while the $33.5 \%$ gap has been dumped into the error term which represent the stochastic element of the model.

Table 8. ANOVA

\begin{tabular}{|c|l|c|c|c|c|c|}
\hline \hline \multicolumn{2}{|c|}{ Model } & Sum of Squares & Df & Mean Square & F & Sig. \\
\hline \hline \multirow{2}{*}{1} & Regression & 75.981 & 3 & 36.097 & 397.449 & $.000^{\mathrm{a}}$ \\
\cline { 2 - 7 } & Residual & 32.312 & 1494 & .086 & & \\
\cline { 2 - 7 } & Total & 108.293 & 1494 & & & \\
\hline \hline
\end{tabular}

a. Predictors: (Constant), Saving mobilization, E-banking platform usage by the rural dweller, Financial decision of the rural dweller

b. Dependent Variable: Financial Literacy.

S o u r c e : author's computation, 2020.

The above result shows a general p-value of 0.000 is $<0.05$ significance margin. This posits that the model is statistically significant. The F-Statistics of 397.449 s was equally significant at $5 \%$ which posits that the overall regression model is fit. 


\section{CONCLUSION AND RECOMMENDATIONS}

Based on the empirical analysis of the research, it was revealed that a positive relationship exists between saving mobilization and financial literacy. A percentage increase in saving mobilization activities will no doubt promote the level of financial literacy within the study area considering the fact that saving mobilization activities of MFIs will no doubt promote a better financial planning and debt management of the MFIs customers especially the rural dwellers that have no access to formal financial service. E-banking product (EBP) and financial decision (FD) as a proxy for the independent variable equally shows to have strong positive relationship with financial literacy. Access and usage of E-banking products by the rural dwellers will no doubt improve their level of financial numeracy and literacy thereby promoting a better financial decision. Revelations from the x-ray of this study shows that the activities of MFIs usually influence an improved financial planning, saving habit and debt management of the MFIs customers especially the rural dwellers that have no access to formal financial service considering the reported coefficient of microfinance institutions operation (MFIO), E-banking product (EBP) and financial decision (FD) as a proxies for the independent variable. A good financial literacy in the population will no doubt induce the level of financial inclusion, which is off course a widely accepted poverty reduction strategy aimed at improving access to financial products for those in viscous circle of poverty partly because of their financial literacy. In the light of the forgoing the following recommendations were made: The Government should promote financial sector deepening by licensing more microfinance institutions, to promote accessibility to finance among its populous to improve the level of financial literacy in north central geo-political zone in Nigeria. This will increase their ability to save and borrow thereby contribute positively to economic development by reducing the level of poverty among the rural dwellers.

\section{REFERENCES}

Abifarin, O., \& Bello, A. (2018). Cooperative Bank as an Effective Financial Inclusion Strategy in Nigeria. Journal of Law, Policy and Globalization, 44.

Adeola, O., \& Ikpesu, F. (2019). An empirical investigation of the impact of bank lending on agricultural output in Nigeria: A vector autoregressive (VAR) approach. Journal of Developing Areas, Tennessee State University, College of Business, 50(6), 89-103. 
Ajinaja, T., \& Odeyale, A. (2018). Microfinance and the Challenge of Financial Inclusion for SME's Development in Nigeria. IOSR Journal of Business and Management, 19(2), 11-18. http://dx.doi.org/10.9790/487X-1902021118.

Bayer, J., \& Douglas, B. (2009).The effects of financial education in the workplace: Evidence from a survey of employers. Economic Inquiry, 47(4), 605-624. http://dx.doi. org/10.1111/j.1465-7295.2008.00156.x.

Chibba, M. (2009). Financial Inclusion, Poverty Reduction and the Millennium Development Goals. European Journal of Development Research, 21(2), 213-230. http:// dx.doi.org/10.1057/ejdr.2008.17.

Emeka, E., \& Udom, A. (2019). Impact of Microfinance in Promoting Financial Inclusion in Nigeria. Journal of Business Theory and Practice, 3(2), 139-158. http://dx.doi. org/10.22158/jbtp.v3n2p139.

Gine, P. (2013). Finance and growth: theory and new evidence. Federal Reserve Board Discussion, 35.

Greenspan, A. (2002). Financial Literacy: A Tool for Economic Progress. Futurist, 36(4), 37-41.

Henri, J.T., Fred, M., \& Kemirembe, O.M. (2015). The role of Financial Literacy on Loan Repayment among small and medium entrepreneurs in Rwanda; case study of Urwego Opportunity Bank. Journal of Small Business and Entrepreneurship Research. 3(5), 33-66.

Kakande, T. (2013). Impact Microfinance Banks on Financial Literacy in Uganda. Issues in Business Management and Economics, 1(7), 193-199.

Lusardi, A. (2008). Financial Literacy: An Essential Tool for Informed Consumer Choice. Paolo Baffi Centre Research Paper, 2009-35, 1-29. http://dx.doi.org/10.2139/ ssrn.1336389.

Lusardi, A. (2012). Numeracy, Financial Literacy, and Financial Decision-Making. Numeracy, 5(1), 1-12. http://dx.doi.org/10.5038/1936-4660.5.1.2.

Masok, C. (2011). Towards an Effective Framework for Financial Literacy and Financial Consumer Protection in Uganda. Kampala: Bank of Uganda.

Mohamed, M.A., \& Mukhongo, A.L. (2016). Effects of Microfinance Services on the Financial Performance of Small and Medium Enterprises in Mogadishu, Somalia. Journal of Business Management, 2(9), 152-173.

Sanusi, L.S. (2011). Financial Inclusion for Accelerated Micro, Small and Medium Enterprises Development: The Nigerian Perspective. Paper presented at the 2011 Annual Microfinance and Entrepreneurship Awards.

Skinner, F.B. (1953). Development and Learning. Journal of Research in Science Teaching, 2(1), 176-186.

Socol, A. (2014). From Literacy to Financial Education: A Survey of Methods to Measure Phenomena. The Particular Situation Of Romania. Annales Universitatis Apulensis Series Oeconomica, 16(1), 213-220. http://dx.doi.org/10.29302/oeconomica.2014.16.1.19. 


\section{INDEX}

QUESTIONNAIRE INSTRUCTION: Please tick $(\sqrt{ })$ against your responses in the space provided.

\section{SECTION A: DEMOGRAPHIC DATA}

1. Age (tick appropriately) 18-29 ( ) $30-49$ ( ) 50 and Above ()

2. Gender: Male ( ) Female ()

3. Marital status: Single () Married ()

4. Occupation: Civil servants () Corporate employee () Entrepreneur ( ) Student ( )

NB; from the next section, kindly tick appropriately,

SA $=\mathbf{5}=$ STRONGLY AGREED

A $=4$ = AGREED

$\mathrm{I}=3$ = INDIFFERENCE

$\mathrm{D}=\mathbf{2}=$ DISAGREE

SD = 1 = STRONGLY DISAGREED

\section{SECTION B}

\section{Operational Information}

I. Establish the relationship between saving mobilization and financial literacy

\begin{tabular}{|c|c|c|c|c|c|c|}
\hline$S / N$ & STATEMENT & SA & A & I & D & SD \\
\hline 1. & SM improves customers financial literacy & & & & & \\
\hline 2. & $\begin{array}{l}\text { SM improves customers understanding of } \\
\text { financial services }\end{array}$ & & & & & \\
\hline 3. & $\begin{array}{l}\text { SM influence customers disposition to ban- } \\
\text { king culture. }\end{array}$ & & & & & \\
\hline 4. & SM induce customers financial knowledge & & & & & \\
\hline
\end{tabular}


II. Analyze the effect of microfinance institutions operations on E-banking platform usage by the rural dwellers

\begin{tabular}{|c|l|c|c|c|c|c|}
\hline \hline S/N & \multicolumn{1}{|c|}{ STATEMENT } & SA & A & I & D & SD \\
\hline \hline 5. & $\begin{array}{l}\text { MFIO brings E-banking products close to } \\
\text { the rural dwellers }\end{array}$ & & & & & \\
\hline 6. & $\begin{array}{l}\text { MFIO influence rural dwellers disposition } \\
\text { to e-banking usage. }\end{array}$ & & & & & \\
\hline 7. & $\begin{array}{l}\text { MFIO improves rural dwellers knowledge } \\
\text { on e-banking products. }\end{array}$ & & & & & \\
\hline 8. & $\begin{array}{l}\text { e-banking products has improved the } \\
\text { level of financial inclusion among the } \\
\text { rural dwellers. }\end{array}$ & & & & & \\
\hline
\end{tabular}

III. Identify the effects of microfinance institutions operations on the financial decisions of the rural dwellers

\begin{tabular}{|c|c|c|c|c|c|c|}
\hline$S / N$ & STATEMENT & SA & A & $\mathbf{I}$ & D & SD \\
\hline 9. & MFIO induce rural dwellers investment decision & & & & & \\
\hline 10. & MFIO improves the rural dwellers saving culture & & & & & \\
\hline 11. & $\begin{array}{l}\text { MFIO improves the rural dwellers financial de- } \\
\text { cision. }\end{array}$ & & & & & \\
\hline 12. & $\begin{array}{l}\text { MFIO has reduce the fear of loss of fund on finan- } \\
\text { cial instrument among the rural dwellers. }\end{array}$ & & & & & \\
\hline
\end{tabular}

